\title{
Assessment of radon gas using passive dosimeter in Amman and Al-Rusaifa cities, Jordan
}

\author{
M.K. Alqadi*, F.Y. Alzoubi, M.A. Jaber \\ Department of physics, Jordan University of Science and Technology, Irbid, Jordan
}

\section{- Short report}

*Corresponding author:

Dr. M.K. Alqadi,

Fax: +96227201071

E-mail: malqadi@just.edu.jo

Revised: Dec. 2015

Accepted: Jan. 2015

Int. J. Radiat. Res., October 2016; 14(4): $367-371$

DOI: 10.18869 /acadpub.ijrr.14.4.367

\section{ABSTRACT}

Background: Radon concentration was measured in the soil and indoor of Amman and Al- Rusaifa cities in Jordan during summer season. Materials and Methods: The measurement was performed using time-integrated passive radon dosimeters, containing a solid state nuclear track plastic detector, commercially known as CR-39. Results: Radon concentration levels in the soil ranged from $2.8 \pm 1.2$ to $6.9 \pm 1.5\left(\mathrm{kBq} / \mathrm{m}^{3}\right)$ with an average $4.0 \pm 1.6(\mathrm{kBq} /$ $\mathrm{m}^{3}$ ) in Amman and from and $6.5 \pm 1.1$ to $22.4 \pm 5.2 \mathrm{kBq} / \mathrm{m}^{3}$ in Al- Rusaifa with average $14.2 \pm 2.5\left(\mathrm{kBq} / \mathrm{m}^{3}\right)$. The average indoor radon concentration in the first floor in Amman was 44.8 $5.3\left(\mathrm{~Bq} / \mathrm{m}^{3}\right)$; while the average concentration in Al- Rusaifa, in the first floor, was $187 \pm 16.35\left(\mathrm{~Bq} / \mathrm{m}^{3}\right)$. In AlRusaifa, our results in the ground floor and the first floor were about $11 \%$ - 26 $\%$ higher than the reported values, while this ratio reaches to $56 \%$ of the soil. Conclusion: The average indoor radon concentration indoor in Al-Rusaifa exceeds the action radon level recommend by WHO $\left(100 \mathrm{~Bq} / \mathrm{m}^{3}\right)$. The potential health impact in this city is considered high. High radon level in AlRusaifa may be due to the phosphate content in its soil. A correlation between the radon concentration in the soil and indoor was observed.

Keywords: Radon, passive dosimeter, Amman, Al- Rusaifa.

\section{INTRODUCTION}

People are used to be exposed to different types of radiations during their daily life. Some of these radiations are harmful to the human body if they exceed specific limits. The origin of these radiations varies between natural sources that result from the existence of many radiating elements within the earth's crust and artificial sources that result from industry and other human scientific and military activities. One of the natural sources of radiation is the radon gas which is considered as a main cause of lung cancer in addition to smoking (1). This gas exists in all places around us at different concentrations varies according to the type of soil as well as the type of building blocks. During breathing, radon may stick to the lung tissues and start emitting alpha particles that will result in a serious biological damage.

Many studies have carried out around the world to measure radon concentration indoor, soil and water as well as to verify its exposure effects on human health (2-8). In Jordon, there are several studies reported a survey of radon levels in soil and indoor at different cities and geological regions, for example, Khatibeh et al. (9) measured the radon concentration in different cities in Jordan. Their measurements showed that the average concentration of radon in Amman city was $43 \mathrm{~Bq} / \mathrm{m}^{3}$. Kullab et al. (10) performed a study on radon in the KG's school in Amman and found that the concentration of radon was $76 \mathrm{~Bq} / \mathrm{m}^{3}$. Kullab et al. (11) measured the radon concentration in three regions in the west of Amman and seven regions in Al-Rusaifa using an active and passive radon monitors. They found that the average concentration of radon gas in Amman and Al-Rusaifa in the ground and first floor was about $199.3 \mathrm{~Bq} / \mathrm{m}^{3}$ and $138.2 \mathrm{~Bq} / \mathrm{m}^{3}$ during the summer season, while the average concentration of radon in the 
soil was $6.0 \mathrm{kBq} / \mathrm{m}^{3}$.

Although, Al-Rusaifa was built close to an old phosphate mine and highly populated $(500,000$ inhabitations in $50 \mathrm{Km}^{2}$ ), a limited radiological studies $(8,11)$ were performed to measure the radon concentration and the radionuclides content in its environment.

In this study, we measured the concentration of radon gas in Al-Rusaifa city $(15 \mathrm{Km}$ from Amman) and in three districts within the east of Amman city that are close to Al-Rusaifa and high populated as well. This part of study is continuation of the previous study (11) which covered the west of Amman. Variation of radon concentration versus floor elevation was investigated. The present study is a part of national project to build a database and map of radon distribution in Jordan.

\section{MATERIALS AND METHODS}

Three hundred dosimeters; which previously calibrated by Al-Bataina et al. (12); were prepared using plastic sheets made of digycol carbonate (CR-39). The CR-39 sheets cut into small pieces of $1.5 \mathrm{~cm} \times 1.5 \mathrm{~cm}$. Each dosimeter was given a certain number and a code, to recognize it.

Every piece was fixed in the bottom of the plastic can and sealed by a cover which has a hole of diameter $1.5 \mathrm{~cm}$ which filled with a piece of sponge of thickness $1 \mathrm{~cm}$ to prevent impurities and short-life Radon isotopes from leaking into the dosimeter. Dosimeters were distributed over the studying area, figure 1, in July 2013.

80 dosimeters were buried upside down in the soil for 14 days at a depth of $50 \mathrm{~cm}$ while 220 dosimeters distributed indoors for 70 days. After collecting the dosimeters; the detectors were removed and soaked in a chemical solution in a process known as chemical etching (13).

The tracks of alpha particle on CR39 were manually counted by taking 30 different fields of view for each detector using optical microscope, and then the average track density and standard deviation were calculated. The radon concentration in units $\mathrm{Bq} / \mathrm{m}^{3}$ was calculated by using the following equation 1 (12).

Int. J. Radiat. Res., Vol. 14 No. 4, October 2016

$$
c=\frac{c_{0} t_{0} \rho}{\rho_{0} t}
$$

Where:

$\mathrm{C}_{0}$ : The radon concentration of the calibration chamber $\left(90 \mathrm{KBq} / \mathrm{m}^{3}\right)$

$t_{0}$ : The calibration exposure time (48 hours)

$\rho_{0}$ : Tracks density on calibration dosimeters in unit (tracks $/ \mathrm{cm}^{2}$ ) and its value is 33400

$\rho$ : The measured tracks density on calibration dosimeters in unit (tracks $/ \mathrm{cm}^{2}$ )

$\mathrm{t}$ : The exposure time

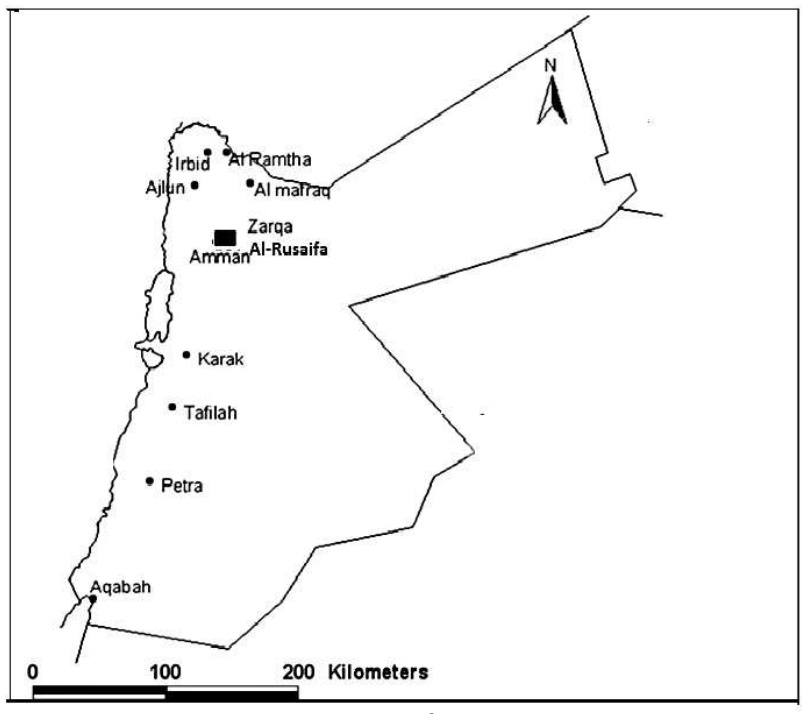

Figure 1. Location of the study area.

\section{RESULTS AND DISCUSSION}

The Radon concentrations in the soil of Amman regions and Al-Rusaifa in unit $\mathrm{Bq} / \mathrm{m}^{3}$ are listed in the table 1 . The radon concentration in Amman's soil ranged from $2.9 \pm 0.8\left(\mathrm{kBq} / \mathrm{m}^{3}\right)$ to $6.9 \pm 1.5 \mathrm{kBq} / \mathrm{m}^{3}$. The highest radon concentration in Amman was in Al-Nassir region (6.9 \pm 1.5 $\left(\mathrm{kBq} / \mathrm{m}^{3}\right)$ where the type of the rocks is limestone. The concentration of radon in Suwaileh and Al-Nuzha are slightly the same $2.97 \pm 0.7$ and $3.2 \pm 0.9\left(\mathrm{kBq} / \mathrm{m}^{3}\right)$ respectively, this can be attributed to similarity of the soil content of both regions.

The average of radon gas concentration in the soil of Amman is equal to $4.0 \pm 1.6\left(\mathrm{kBq} / \mathrm{m}^{3}\right)$, which falls within the accepted limits $(50 \mathrm{kBq} /$ $\left.\mathrm{m}^{3}\right)^{(14) \text {. }}$

Several factors influence the value of the 
indoor radon concentration, such as building materials, ventilation, geological formations, and water supply. Variation of indoor radon concentration in Amman according to floors level is presented in table 2 . The highest value recorded in the air in Amman was on the ground floor of Al Nassir, and it was $85.2 \pm 8.3\left(\mathrm{~Bq} / \mathrm{m}^{3}\right)$ while, the lowest value was recorded at the third floor in $\mathrm{Al} \mathrm{Nuzha}$ and it was $8.43 \pm 0.9\left(\mathrm{~Bq} / \mathrm{m}^{3}\right)$. It is clear that the lowest average concentration of radon gas in Amman was found in Suwaileh. The height of this region $(1100 \mathrm{~m}$ above the sea level) gives a natural ventilation source that reduces Radon concentration. In addition, the buildings in this area are made of sedimentary rocks.

In general, the concentration of radon in ground floor was about 2.5 times the radon concentration in the third floor in the area of study. One of the main objectives of this study was to figure out the radon concentration in AlRusaifa city due to its richness of phosphate ore. Table 1 shows that the maximum value of radon concentration in the soil of Al-Rusaifa was $22.4 \pm$ $5.2\left(\mathrm{kBq} / \mathrm{m}^{3}\right)$, and the minimum value was $6.5 \pm$ $1.1 \mathrm{kBq} / \mathrm{m}^{3}$ while the average concentration was $14.2 \pm 2.5 \mathrm{kBq} / \mathrm{m}^{3}$. This result is about $56 \%$ higher than the previous study performed by Kullub (11) who found that radon concentration was about $6 \mathrm{kBq} / \mathrm{m}^{3}$ during the summer season.

Table 2 summarizes the results of indoor Radon concentration in Al-Rusaifa as a function of floor level. It is clear that the maximum Radon concentration was in the ground floor 300 $\pm 25.5\left(\mathrm{~Bq} / \mathrm{m}^{3}\right)$, and the minimum value was recorded in the third floor $35.4 \pm 2.5\left(\mathrm{~Bq} / \mathrm{m}^{3}\right)$. From table 2, we found that the radon concentration in the ground floor was almost 3 times its value in the third floor. In this region, the radon level in the ground, first, second floors exceeds the recommended level of radon by WHO $\left(100 \mathrm{~Bq} / \mathrm{m}^{3}\right){ }^{(15)} \mathrm{but}$ it is still less than the Jordanian level (200) Bq/ $\mathrm{m}^{3}$.

Our results in the ground floor and the first floor were about $11 \%$ - $26 \%$ higher than the radon concentration in the previous study. The reason for the difference between our results and Kullub's (11) study may be due to the fact that they computed the average of radon concentration in Amman and Al- Rusaifa together, which reduce the value of the radon concentration.

Figure 2 shows that the radon concentration in the first floor in the regions: Al-Nusha, $\mathrm{Al}$

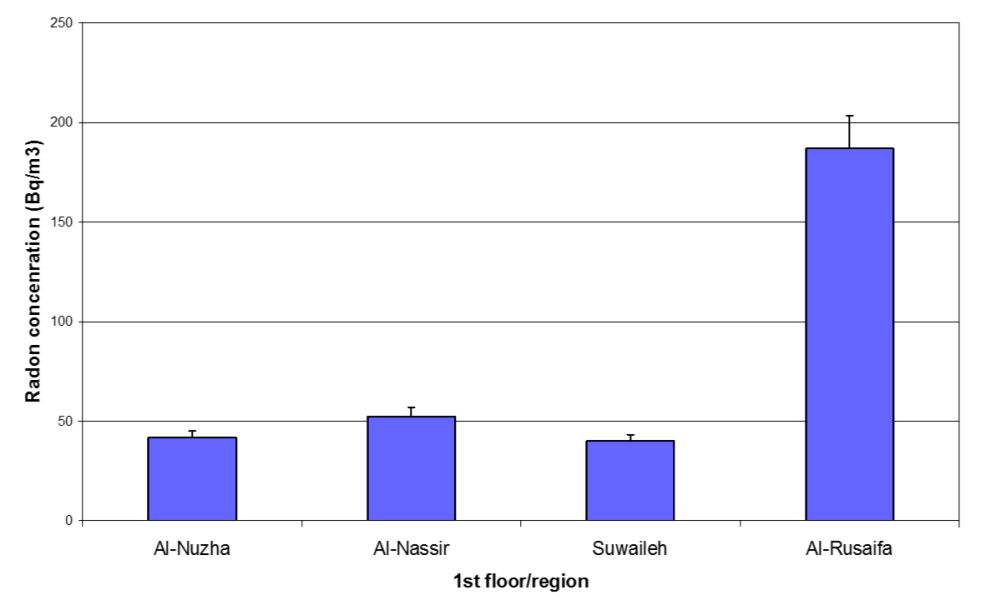

Figure 2. Average radon gas concentration in the first floor in Amman and Al Rusaifa cities.

Table 1. Radon gas concentration in the soil.

\begin{tabular}{|c|c|c|c|}
\hline Region's name & $\begin{array}{c}\text { Min. value concentration } \\
\left(\mathrm{KBq} / \mathbf{m}^{3}\right)\end{array}$ & $\begin{array}{c}\text { Max. value concentration } \\
\left(\mathrm{KBq} / \mathbf{m}^{3}\right)\end{array}$ & $\begin{array}{c}\text { Avg. value concentration for all } \\
\text { samples }\left(\mathrm{KBq} / \mathbf{m}^{3}\right)\end{array}$ \\
\hline Al-Nuzha & $0.8 \pm 2.9$ & $1.3 \pm 5.8$ & $0.9 \pm 3.2$ \\
\hline Al-Nassir & $0.7 \pm 3.4$ & $1.5 \pm 6.9$ & $1.3 \pm 5.4$ \\
\hline Suwaileh & $1.2 \pm 2.8$ & $1.1 \pm 4.6$ & $0.7 \pm 2.97$ \\
\hline Al-Rusaifa & $1.1 \pm 6.5$ & $5.2 \pm 22.4$ & $2.5 \pm 14.2$ \\
\hline
\end{tabular}


Table 2. Indoor radon gas concentration in Amman and Al Rusaifa cities.

\begin{tabular}{|c|c|c|c|c|}
\hline & Floor No. & Min concentration $\left(\mathrm{Bq} / \mathrm{m}^{3}\right)$ & Max concentration $\left(\mathrm{Bq} / \mathrm{m}^{3}\right)$ & Avg concentration $\left(\mathrm{Bq} / \mathrm{m}^{3}\right)$ \\
\hline \multirow[t]{4}{*}{ Al-Nuzha } & Basement & $4.2 \pm 45.29$ & $3 \pm 75.62$ & $3.6 \pm 61.45$ \\
\hline & 1st floor & $2 \pm 20.57$ & $4.2 \pm 73.4$ & $3.1 \pm 42$ \\
\hline & 2nd floor & $1.1 \pm 18.43$ & $3.7 \pm 55.6$ & $2.35 \pm 37$ \\
\hline & 3rd floor & $0.9 \pm 8.43$ & $4.5 \pm 35.36$ & $2.7 \pm 25$ \\
\hline \multirow[t]{4}{*}{ Al-Nassir } & Basement & $2.8 \pm 42.32$ & $8.3 \pm 85.2$ & $5.7 \pm 67.7$ \\
\hline & 1st floor & $2.0 \pm 35.28$ & $5.08 \pm 75.32$ & $4.4 \pm 52.3$ \\
\hline & 2nd floor & $2.5 \pm 26.8$ & $5.50 \pm 63.81$ & $3.6 \pm 40.53$ \\
\hline & 3rd floor & $1.01 \pm 17.18$ & $3.4 \pm 48.2$ & $2.2 \pm 28.7$ \\
\hline \multirow[t]{4}{*}{ Suwaileh } & Basement & $0.8 \pm 40.4$ & $5.1 \pm 63$ & $4.45 \pm 57.1$ \\
\hline & 1st floor & $2.1 \pm 31.18$ & $4.36 \pm 44.8$ & $3.23 \pm 40.1$ \\
\hline & 2nd floor & $1.3 \pm 25.6$ & $2.86 \pm 36.18$ & $2.07 \pm 34.9$ \\
\hline & 3rd floor & $1.02 \pm 17.96$ & $3.1 \pm 30.5$ & $2.57 \pm 22.23$ \\
\hline \multirow[t]{4}{*}{ Al-Rusayfah } & Basement & $9.8 \pm 115$ & $25.5 \pm 300$ & $20.5 \pm 225$ \\
\hline & 1st floor & $6.8 \pm 83$ & $18.6 \pm 225$ & $16.35 \pm 187$ \\
\hline & 2nd floor & $4.5 \pm 53.5$ & $15.5 \pm 177$ & $11.4 \pm 125$ \\
\hline & 3rd floor & $2.5 \pm 35.4$ & $8.5 \pm 95.6$ & $6.5 \pm 77.7$ \\
\hline
\end{tabular}

-Nassir, Suwaileh and Al-Rusaifa. It is clear that there was a slightly difference in the radon concentration among the regions in Amman. It can be seen, the concentration of radon in AlRusaifa is four times the concentration of radon in Amman. In general, the variation of radon concentration among the regions may be attributed to three main factors: the nature of soil, the building Materials, and the ventilation conditions.

Cross (16) estimated the probability to have lung cancer due to radon gas exposure by $3.5 \times 10^{-3}$ when the concentration of radon was 1pci/L. Our estimations for this probability in Amman and Al-Rusaifa were $4.3 \times 10^{-3}$ and $18.1 \times 10^{-3}$ respectively, that means 43 or 181 individuals out of 10000 are probable to get lung cancer, especially for people aged between 70 76 years old residing in both Amman and AlRusaifa.

\section{CONCLUSION}

There are considerable variations in radon concentration between the east of Amman and Al-Rusaifa due to the difference in the geological formation of soil. A slightly difference in radon concentration among the areas of study in Amman was found. In Al-Rusaifa, the average of indoor radon concentration exceeds the action radon level recommend by WHO $\left(100 \mathrm{~Bq} / \mathrm{m}^{3}\right)$. Therefore, increasing a public awareness to health impact of radon risk should be provided in this region.

\section{Conflict of interest: Declared none.}

\section{REFERENCES}

1. Pershagen G (1994) Residental Radon Expusure and Lung Cancer in Sweden. N Engl J Med, 330: 159-164.

2. Gunning GA, Pollard D, Finch EC (2014) An outdoor radon survey and minimizing the uncertainties in low level measurements using CR-39 detectors. J Radiol Prot, 34: 457-467.

3. Aleissa KA, Alghamdi AS, Almasoud FI, Islam MS (2012) Measurement of radon levels in groundwater supplies of Riyadh with liquid scintillation counter and the associated radiation dose. Radiat Prot Dosimetry, 154 (1): 95-103.

4. Khan MS, Naqvi AH, Azam A, Srivastava DS (2011) Radium and radon exhalation studies of soil Iran J Radiat Res, 8 (4): 207-210.

5. Bouzarjomehri F and Ehrampoosh MH (2008) Radon level in dwellings basement of Yazd-Iran. Iran J Radiat, 6 (3): 141-144.

6. Bossew $P$ and Lettner $H$ (2007) Investigations on indoor 
radon in Austria, Part 1: Seasonality of indoor radon concentration. J Environ Radioact, 98: 329-345.

7. Sharma DK, Kumar A, Kumar M, Singh S (2003) Study of uranium, radium and radon exhalation rate in soil samples from some areas of Kangra district, Himachal Pradesh, India using solid-state nuclear track detectors. Radiat Meas, 36: 363-366.

8. Al-Jundi J (2002) Population doses from terrestrial gamma exposure in areas near to old phosphate mine, Russaifa, Jordan. Radiat Meas, 35: 23-28.

9. Khatibeh A, Ahmad N, Matiullah Kenawy M, Abumurad K, Kullab M, Al- M, Al-Bataina B (1997) Measurements of indoor radon concentration levels in some cities of Jordan. Radiat Meas, 28(1-6): 589-590.

10. Kullab MK, Al-Bataina BA, Ismail AM, Abumurad KM, Ghaith A (1997) Study of radon-222 concentration levels inside Kindergartens in Amman. Radiat Meas, 28: 699702.
11. Kullab MK, Al-Bataina BA, Ismail AM, Abumurad KM (2001) Seasonal variation of radon-222 concentrations in specific locations in Jordan. Radiat Meas, 34: 361-364.

12. Al-Bataina BA, Ismail AM, Kullab MK, Abumurad KM, Mustafa H (1997) Radon measurements in different types of natural waters in Jordan. Radiat Meas, 28(1-6): 591594.

13. Durrani SA and Bull RK (1987) Solid state nuclear track detection "Principles, Method and Applications". Oxford, Pergamon Press, 321-324.

14. Nizaroff WW and Nero AV (1988) Radon and its decay products in indoor air. New York: John Wiley \& Sons.

15. WHO (2009) Handbook on Indoor: A Public Health Perspective, WHO Press, Geneva.

16. Cross FT (1992) Indoor radon concentration and lung cancer: Reality or Mith. Twenty-ninth Hanford on Health and Environmental, Bettelle Press. Columbus, 27-29. 
